\title{
Charles E. Culpeper Foundation Scholarships in Medical Science
}

The Charles E. Culpeper Foundation is currently accepting applications for its Year 2000 Scholarships in Medical Science Program designed to support the career development of academic physicians.

Up to four awards of USD 100,000/year for 3 years will be made to United States medical schools or equivalent United States educational institutions on behalf of candidates who are US citizens or aliens who have been granted permanent US residence (proof required); who have received their MD degree from a US medical school or the equivalent of an MD degree from an educational institution equivalent to a United States Medical School in 1991 or later (except under extraordinary circumstances, as approved by the Foundation), and who are judged worthy of support by virtue of the quality of their research proposals. All scientific research relevant to human health is eligible for consideration. No institution may nominate more than one candidate.

In selecting awardees, emphasis will be on identifying young physicians with clear potential for making substantial contributions to science as academic physicians. Since January 1988, 37 physicians have been selected as Charles E. Culpeper Foundation Medical Scholars.

Deadline for applications is August 16, 1999. Awards will be announced in January 2000, for activation on or about July 1, 2000. Application forms and instructions may be obtained on the Web at www.culpeper.org or by contacting:

The Charles E. Culpeper Foundation

Financial Centre

695 East Main Street

Stamford, CT 06901-2155 (USA)

Tel. +1 203975 1240, Fax +1 2039751847 


\section{B. Grabensee}

\section{Checkliste Nephrologie}

Thieme, Stuttgart 1998

464 pp.; DEM 64.-

ISBN 3-13-106331-9

This book is the size of a paperback, beautifully produced, and packed with carefully arranged information. It is one of a series covering different specialties, and this volume has a remarkably competent choice of all aspects of clinical nephrology, and is up-to-date. It even includes details on PET in CAPD, Kt/V and even drug metabolism in renal failure. The foreword suggests that it is intended for general medicine trainees, but the details are so rich and carefully chosen to be practical, that certainly it would be wise for all Germanspeaking nephrology trainees to keep a copy in their pocket when they are in their first 6 months of nephrology training. The book is adequately illustrated and is a pleasure to read because it is so precisely written. The book should be translated into English so as to make it available to English speakers who are otherwise denied its benefits. Prof. Grabensee should be congratulated for having made this valuable teaching volume so concise and up-to-date.

G.M. Berlyne

\section{S.L. Bonnick}

\section{Bone Densitometry in Clinical Practice}

Humana Press, Clifton 1998

257 pp.; USD 89.50

ISBN 0-89603-513-1

To those nephrologists who have been presented with an unintelligible bone density report, this book is a revelation.

It describes in detail the various methods of measuring densitometry of bone, including anatomy and statistical analyses which figure so prominently in densitometry reports, also precision of measurement, quality control and then the various physiological and pathological conditions which are associated with bone density changes, e.g., aging, hyperparathyroidism and other endocrine diseases. However, there are only two paragraphs devoted to renal disease. Perhaps more data interesting nephrologists could be included in future editions.

G.M. Berlyne

\section{KARGER}

(c) 1999 S. Karger AG, Basel

Fax +41613061234

E-Mail karger@karger.ch www. karger.com
Accessible online at: http://BioMedNet.com/karger 